ROCZNIKI HUMANISTYCZNE

Tom LXVIII, zeszyt $11-2020$

DOI: https://doi.org/10.18290/rh206811-14

BEATRIZ VALVERDE

\title{
FOREIGN-SPACE DRAMATIZATION IN GRAHAM GREENE'S THE POWER AND THE GLORY: REVISITING GREENELAND
}

\begin{abstract}
A b stract. Graham Greene was a frequent traveler and he commonly chose different spaces around the world as settings for his novels. Critics have generally agreed, however, that the British author created in his novels an a-topos, a space that conformed not to the reality of the country depicted, but to the development of the topics, spiritual or political, with which Greene was obsessed. That atopical location became over time what has been called Greeneland, a concept with which any Greene scholar inevitably becomes familiar. In this paper, I revisit the concept of Greeneland, arguing that scholars tend to focus on the major themes present in Greene's literary world and to ignore the fact that a close analysis of the fictional landscape in his work challenges the assertion that what Greene created in his novels was a mental entity, a non-place. In order to do so, I focus on the representation of space and society in Greene's The Power and the Glory (1940), the Mexico of the religious persecution of the late 1920s. I compare Greene's representation with the Mexico of the same period depicted in Juan Rulfo's Pedro Páramo (1955), a novel whose fictional landscape bears uncanny resemblances to the one described in The Power and the Glory. This analysis leads us to rethink the concept of Greeneland as generally defined in the criticism.
\end{abstract}

Keywords: Greene; Rulfo; The Power and the Glory; Pedro Páramo; Greeneland.

Graham Greene was a frequent traveler and, as a writer, commonly chose different spaces around the world as settings for his literary work. Specifically, as Charles Duffy states, Greene has settings "in some twenty-two lands on four continents" (15). Criticism has generally agreed, however, that the British author created in his novels an a-topos, a space that conformed not to the reality of the country depicted, but to the development of the topics, spiritual or political, with which Greene was obsessed. That atopical space became over

Beatriz Valverde is Assistant Professor at the University of Jaén; address for correspondence: Campus las Lagunillas, Building D2, 23071 Jaén, Spain; e-mail: bvalverd@ujaen.es; ORCID: https://orcid.org/0000-0003-1918-4447. 
time what has been called Greeneland, a concept with which any Greene scholar inevitably becomes familiar ${ }^{1}$ and which the British author himself utterly disliked all his life. In his autobiography, Ways of Escape, he writes:

Some critics have referred to a strange violent "seedy" region of the mind ... which they call Greeneland, and I have sometimes wondered whether they go round the world blinkered. "This is Indochina," I want to exclaim, "this is Mexico, this is Sierra Leone carefully and accurately described. I have been a newspaper correspondent as well as a novelist. I assure you that the dead child lay in the ditch in just that attitude. In the canal of Phat Diem the bodies stuck out of the water..." But I know that argument is useless. They won't believe the world they haven't noticed is like that. $(80)^{2}$

The concept of Greeneland was coined in 1940 by Arthur Calder-Marshall in his review of The Power and the Glory for the journal Horizon (McEwan 17). Greeneland has since been interpreted on many occasions as mere mental recreations that have almost nothing to do with the places that inspired those sceneries (Pearson 214). In this sense, Peter Mudford asserts that "[a]lthough [Greene's] novels were set in many different countries, his attitudes and his beliefs were, like those of his contemporaries, Eurocentric" (12). In this paper, I revisit the concept of Greeneland, arguing that scholars tend to focus on the major themes present in Greene's literary world and to ignore the fact that a close analysis of fictional landscape in his work challenges the assertion that what Greene created in his novels was a mental entity, a non-place. In order to do so, I focus on the representation of material space and social groups in Greene's The Power and the Glory (1940), the Mexico of the religious persecution of the late 1920s. I compare Greene's representation with the Mexico of the same period depicted in Juan Rulfo's Pedro Páramo (1955), a novel whose fictional space bears uncanny resemblances to the one described in The Power and the Glory.

\footnotetext{
${ }^{1}$ It is practically impossible to read a scholarly piece about the work of Graham Greene without coming across the term Greeneland. There are as many definitions of the term as critics using it, but the majority of them ignore the spatial component to focus on moral, spiritual or psychological elements. To offer just some examples, Neil Sinyard defines it as "a distinctive physical, psychological, and moral terrain" (116), while Mark Bosco refers to it as "a landscape filled with lonely, pathetic, and sometimes malevolent characters (25). In this sense, an adjective closely related to the critics' idea of Greeneland is "seedy," a word Calder-Marshall used in his review for Horizon, stating that Graham Greene's novels were characterised by a seedy terrain that should be called Greeneland (Watts, "Darkest" 133).

${ }^{2}$ As Franklin observes, to prove his point, Greene extracted a promise from his official biographer, Norman Sherry, to follow in his footsteps to wherever he had set a major work (Franklin par. 3).
} 
Critics have considered Greene's depiction of Mexico in The Power and the Glory "a mental entity, a stimulus of the imagination" (Russel 144). Manuel Rodríguez says that Greene's Mexico is "de cartón piedra y pasiones calientes" (88) (made of cardboard and hot passions). Greene sets the novel in the states of Tabasco and Chiapas during the fierce religious persecution carried out by Governor Tomás Garrido Canabal in the late 1920s, enforcing President Plutarco Elías Calles' anticlerical laws. Taking into account the priest's narration of his past life, however, the novel goes back to the beginning of the twentieth century.

Juan Rulfo's Pedro Páramo covers a similar period: the final years of the 19th century (Mexico under General Porfirio Díaz), the Mexican Revolution (1910-1917), finishing after the Cristero War (1929) (Escalante 563). Rulfo sets his novel spatially in the region of Tierra Caliente (Hot Land), a high plateau located in the mountainous central-western area of Mexico. Despite the different locations, we find common aspects in the way both Greene and Rulfo dramatize these territories. In both novels, hostile natural elements become symbolic. Nature is aggressive and leaves people out of breath. Rulfo's character Abundio says of the town of Comala, "That town sits on the coals of the earth, at the very mouth of hell" (6). ${ }^{3}$ In the same vein, Greene's depiction of Tabasco and Chiapas is characterized by the suffocating heat that doesn't let people in Villahermosa breathe (Lanning 40, 41). Some of the expressions Greene uses are "blazing Mexican sun" (7), "merciless sky" (9), "the little burnt plaza" (11), and "the sun came in like a white-hot bar" (16).

A second element of connection is the way Greene and Rulfo represent society in their work. Leaving aside the foreign characters who live in the region, Mexican society in The Power and the Glory is divided into three main strata: the hegemonic group of the governor and his followers, representatives of the Catholic Church, who go from a situation of economic strength before the Revolution to become targets of persecution by the authorities under President Calles, and the poor peasants, who constitute the majority of the population. In Pedro Páramo, the structure of society is analogous. First, we find Pedro Páramo, the landlord who dominates the region; his control over the region is indisputable. When a problem with boundary lines arises, Páramo just says, "What law, Fulgor? From now on, we're the law" (Rulfo 40). Second,

\footnotetext{
${ }^{3}$ González Boixo argues that Rulfo's characters are located in the midst of a reality that is hostile to them. Eventually, everything will collude against them and no relief seems to be expected to change their situation (550).
} 
Father Rentería represents the mighty Catholic Church. And finally, the poor peasants and their families constitute the largest population in Comala.

The poverty in which the majority of Comala's people live is presented in Rulfo's novel mainly through small details in the characters' conversations; such details, taken as a whole, however, offer readers a vivid image of the lives of the workers. During his infancy, Paramo's family belonged, ironically, to the group of poor peasants. The family's unfavorable socio-economic situation after Paramo's grandfather dies is enlightening in this sense. His grandmother tells him, "But with all the money we spent to bury your grandfather, and the tithes we've paid to the church, we don't have anything left" (Rulfo 13). This poverty is exposed as well in the conversation among some of Páramo's workers after his son's burial:

$[T]$ he men were resting after the long walk back from the cemetery....

"That death pained me in more ways than one," said Terencio Lubianes. "My shoulders are still sore."

"Mine, too," said his brother Ubillado. "And my bunions must have swelled an inch. All because the patron wanted us to wear shoes. You'd have thought it was a holy day, right, Toribio?" (Rulfo 29)

A final image of poverty is offered when Dorotea tells Juan Preciado about her dream. In it, she has something taken out of her body: "I wanted to tell them that it was just my stomach, all dried up from hunger and nothing to eat" (Rulfo 61).

In The Power and the Glory, Greene depicts the analogous unfavorable socio-economic situation that the population suffers more explicitly. The whisky-priest goes all over Tabasco while running away from the authorities, and through his eyes we witness the harsh living conditions of Mexican villagers. The descriptions are revealing:

Half a dozen huts of mud and wattle stood in a clearing; two were in ruins. A few pigs routed round, and an old woman carried a burning ember from hut to hut, lighting a little fire on the centre of each floor to fill the hut with smoke and keep mosquitoes away. Women lived in two of the huts, the pigs in another; in the last unruined hut where maize was stored, an old man and a boy and a tribe of rats. (Greene 42$)^{4}$

\footnotetext{
${ }^{4}$ In the final lines of this description, the narrator's parallel structure equates people in their insignificance with animals ("women" with "pigs" as well as "man" and "boy" with "rats"), thereby insisting on the villagers' both physical and psychological degradation.
} 
Finally, to complete the analysis of the structure of the society, in both novels we find a sector of the population that does not belong to the society as such: the Indians. Rulfo depicts them as a choral group that does not take part directly in the action. They are not part of the community of Comala, having limited contact with its inhabitants: "It is Sunday. The Indians have come down from Apango with their rosaries of chamomile, their rosemary, their bunches of thyme.... They spread their herbs on the ground beneath the arches of the arcade. And wait" (Rulfo 86). Religiously speaking, they are a syncretic culture, mixing Catholic beliefs with the ones of their ancestors, ${ }^{5}$ as in the episode of their visit to the Virgin before going back home: "Towards dusk the Indians rolled up their wares... They stopped by the church to pray to the Virgin, leaving a bunch of thyme as an offering" (Rulfo 87).

Similarly, in The Power and the Glory the Indians are also represented as a syncretic social group. A significant episode in this sense is the priest's encounter with the Indian woman who carries her son's dead body to a cemetery in the mountains. The priest's first thought is of the convenient means to bury the child according to the traditional Catholic rite (a spade to dig a proper grave). With no instrument to dig a grave, however, the rite itself seems meaningless. In this light, leaving the body at the foot of a cross with a sugar lump next to the child's mouth - a syncretic rite-finally makes much more sense and is positively valued. ${ }^{6}$

Among the commonalities between the two novels regarding the structure of the society, what stands out as most relevant is the way Greene and Rulfo describe the representatives of the Catholic Church and their leading role within Mexican society. Father Rentería is the main representative of the Catholic Church in Rulfo's novel. His position in the society of Comala is quite influential: even the almighty Pedro Páramo needs him to perform the traditional Catholic rites, such as his wedding with Dolores or his son's burial. However, it is Father Rentería who obeys Páramo's orders because Páramo is the one providing for the priest: "I owe them my livelihood. I get nothing from the poor, and God knows prayers don't fill a stomach" (Rulfo 30). Several episodes in the novel reveal the priest's immoderate ambition when it comes to

\footnotetext{
${ }^{5}$ Religious syncretism is one of the most outstanding features that Ricardo Pozas identifies as characteristic of indigenous culture in his work Juan Pérez Jolote. Significant in this sense are the indigenous versions of the birth of Christ (101) and the figures of the saints (98-101), as well as the identification of the Lord with Mother Earth (97).

${ }^{6}$ According to Daniel Diephouse, this cemetery exemplifies a spontaneous representation of popular religiosity, which is positively valued in the novel (58).
} 
money, such as his blessing Pedro Páramo and Dolores' matrimony even though the priest knows Páramo is only interested in her money. It is through Páramo's eyes that the hypocrisy of the church represented by Father Rentería is shown. Tellingly, when Justina wonders whether Páramo's first wife is in heaven, since she didn't take communion before dying, Páramo answers, "Don't be silly, Justina" (Rulfo 110). Father Rentería's subjugation to Pedro Páramo is complete: even though he knows that Miguel Páramo is responsible for his brother's murder and his niece's rape, he finally blesses him in his burial, accepting the handful of gold coins that Pedro Páramo gives him, in a clear Biblical reference to Judas' betrayal (Rulfo 26). ${ }^{7}$

Father Rentería's attitude towards the poor does not show the same respect, however: he judges their imperfections without any attempt to understand them. As a consequence, his parishioners distance themselves from institutionalized Catholicism. A revealing example is Dorotea's view of heaven:

I lost all interest after padre Rentería told me I would never know glory. Or even see it from a distance.... It was because of my sins, but he didn't have to tell me that. Life is hard enough as it is. The only thing that keeps you going is the hope that when you die you'll be lifted off this mortal coil; but when they close one door to you and the only one left open is the door to Hell, you're better off not being born... (Rulfo 66)

Significant as well is the episode in which María Dyada asks father Rentería to bless her sister even though she has taken her own life. Instead of comforting her, all the priest does is try to get money out of the circumstances despite knowing the poverty in which the family lives. In this vein, as González argues, while Pedro Páramo represents physical violence over the population, the church exercises spiritual violence over them, since it denies the people in Comala the help and the salvation they beg for (559).

The character of the whisky-priest in The Power and the Glory is also a disgrace to the Church. His many imperfections make him consider himself a moral failure. He became a priest to escape poverty, not to answer a calling. What is more, before the religious persecution in Tabasco started, he was full of pride

\footnotetext{
${ }^{7}$ The reference to the gold coins (the silver talents that Judas received), together with the reference shortly afterward to the roosters' crowing (Rulfo 32) (St. Peter's denial of Christ), establishes Rentería's betrayal as one of Christ and of his function as a priest. This episode constitutes his moment of epiphany that will later lead him to join the Cristero guerrillas in an attempt to redeem himself. Whereas some critics interpret this decision as Rentería's search for death (Escalante 574), others believe his act is positive, since Father Rentería finds his place in the rebellion of the Cristeros (Rodriguez Monegal 750).
} 
and led a complacent life, ambitious for money and power (Greene 67, 93). As Watts argues, as a priest on the run, "[h]e is a semi-alcoholic; he has known despair; he has fathered an illegitimate child, and he finds that his love for that child prevents him from being properly penitent for his sexual sin" (Watts, "Janiform" 99). Even though he may seem a heroic figure running away from the oppressive authorities, the priest confesses that he stayed in Tabasco defying the anticlerical laws due to his pride: he wanted to be the only priest remaining in the region (Greene 95).

In this sense, the whisky-priest's life bears uncanny similarities to Father Rentería's. As mentioned before, the priest in The Power and the Glory entered the seminary to escape poverty. Likewise, in Pedro Páramo becoming a priest is seen as a way to enjoy better living conditions, as is made clear when Lucas Páramo tried to send his son to the seminary so that he could eat every day and have the means to provide for his mother once his father died (Rulfo 37-38). In addition, the discourse of both priests towards the poor conveys a normative Catholic teleological message: they should conform to their miserable existence in the hope of gaining their right to Heaven. In Pedro Páramo the message is that earthly life is a vale of tears in which we are destined to suffer (Rulfo 31-32). Suffering is the way to glory in the afterlife. Greene's whisky-priest expresses himself in similar terms when addressing the villagers: "Pain is part of joy. [...] Pray that you suffer more and more. Never get tired of suffering. The police watching you, the soldiers gathering taxes, the beating you always get from the jefe because you are too poor to pay, smallpox and fever, hunger... that is all part of heaven" (Greene 69-70).

Analyzing the religious experience of Catholicism in the Mexican communities described in these two novels, we observe that Father Rentería and the whisky-priest exercise considerable power over women, a situation that directly influences the priests' relationship with their parishioners. Tellingly, it's women who maintain the bond between institutionalized Catholicism and the community in both novels. In Pedro Páramo, a large number of women attend mass every day and go to confession even though Father Rentería often neglects his duty as a confessor to them (Rulfo 70-71). In addition, women are the ones giving the tithes to the church despite the difficult economic situation of their families (Rulfo 13). In The Power and the Glory we witness a closely analogous situation. A clear case of women as bonding the institutional church and the community is Luis' mother, who keeps telling her children stories of saints despite the prohibition of religious books (Greene 25-28). In addition, the whisky-priest is no more interested in hearing confession at 
the beginning of the novel than Father Rentería is. When he gets to the first village, all he does is demand money, alcohol, food, or clothes from the poor peasants. His only wish is to sleep, but he finally agrees, with resignation, to confess a man. Before giving absolution, however, he falls asleep (Greene 46-47). Later in the novel, in his stay in the village between Tabasco and Chiapas, he gets angry with a woman while confessing her because, as with Dorotea in Rulfo's novel, the priest considers that she doesn't have real sins: "[W]hat are you doing here, keeping away the bad people?" (Greene 173).

A final parallel is that both Father Rentería and the whisky-priest go through a deep spiritual evolution. Each eventually acknowledges having betrayed his own people and experiences a sort of final reconciliation with those whom he had formerly despised. In this line of thought, Paula Martín argues that "Greenean ethics is, as Derrida would say, following a Lévinasian approach, an ethics of the other.... Greene's work may be said to explore the potential constitution of forms of community based on ethical action, established as alternative - often opposed - to official or institutional communities" (7). This is the kind of ethics that Rulfo also embraces in Pedro Pára$m o$, with Father Rentería leaving behind his role representing institutionalized Catholicism in Comala to join the rebellion of the Cristeros.

Thus the numerous parallels we have explored between Rulfo's and Greene's dramatization of Mexico and Mexican society pre- and post-revolution demonstrate that Russel's claim that the fictional landscape depicted in The Power and the Glory is just a "mental entity" has no factual basis. Contrary to this view, I agree with critics such as Lanning, who states that Greene's representations of fictional landscapes in Latin America are precise and rigorous (Lanning 3), and Brotherson, who argues that numerous, varied, and valuable literary representations of the Mexico of the Revolution have been written by both Mexican and foreign authors (Brotherson 812).

The comparative analysis carried out here of The Power and the Glory and Pedro Páramo shows that critics' frequent references to Greeneland as a mental landscape or a-topos are questionable. What is more, 'Greeneland' itself is often a matter of gross reductionism, since what critics usually refer to with this term is a set of "mere critical abstractions of otherwise diverse characters, plots, and locales" (Link 77). Criticism has focused on analyzing Greeneland in terms of the writer's religious and political preoccupations, failing to scrutinize Greene's treatment of space in his representations of fictional landscapes. In this sense, challenging the concept of Greeneland as defined by criticism not only questions the appropriateness of using this term in the 
analysis of Greene's work; it also points to a new line of research concerning the work of the English author: the study of the relation of social processes and spatial forms in his novels, drawing upon theoreticians such as Henri Lefebvre, among others. Greene's dramatization of social space is a product of his perceptual mode, a foreign witness's perception of the landscapes he experienced. In this sense, his representation of Mexico in The Power and the Gory does not differ from but complements the view offered by a Mexican author, Juan Rulfo, in Pedro Páramo.

\section{WORKS CITED}

Bosco, Mark. Graham Greene's Catholic Imagination. Oxford UP, 2005.

Brotherson, Gordon. "Provincia de almas muertas." Fell, pp. 808-13.

Diephouse, Daniel. "The Allusiveness of Space in Graham Greene's Novels."

Perceptions of Religious Faith in the Work of Graham Greene, edited by Thomas Hill, Peter Lang, 2002.

Duffy, Charles F. "Ireland and Greeneland: The Irish in the Writings of Graham Greene." Éire-Ireland, vol. 30, no. 3, 1995, pp. 14-26.

Fell, Claude, editor. Juan Rulfo: Toda la obra. Critical Edition, Consejo Superior de Investigaciones Científicas, 1992.

Franklin, Ruth. "God in the Details. Graham Greene's religious realism.” New Yorker, 4 Oct. 2004, www.newyorker.com/magazine/2004/10/04/god-in-the-details. Accessed 10 May 10, 2020.

Escalante, Evodio. “Texto histórico y texto social en la obra de Rulfo.” Fell, pp. 561-81.

Greene, Graham. The Power and the Glory. Penguin Books, 1971.

Escalante, Evodio. Ways of Escape. Penguin, 1981.

González Boixo, José Carlos. “Lectura temática de la obra de Juan Rulfo.” Fell, pp. 549-60.

Lanning, Carmen Nadine. The Ambiente of Five Latin American Novels by Graham Greene. Michigan: UMI, 1986.

Link, Christopher A. "Bad Priest and the Valor of Pity. Shusaku Endo and Graham Greene on the Paradoxes of Christian Virtue." Logos, vol. 4, no. 4, 2012, pp. 75-96.

Martín Salván, Paula. The Language of Ethics and Community in Graham Greene's Fiction. Palgrave Macmillan, 2015.

McEwan, Neil. Graham Greene. Macmillan, 1988.

Mudford, Peter. Graham Greene. Northcode House, 1996.

Pearson, Sheryl. “'Is There Anybody There?' Graham Greene in Mexico.” Journal of Modern Literature, vol. 9, no. 2, 1982, pp. 277-90.

Pozas, Ricardo. Juan Pérez Jolote. México: Fondo de Cultura Económica, 1952.

Rodríguez, Manuel. "El México de Juan Rulfo." Cuadernos cervantinos de la lengua española, vol. 2, 1955, pp. 88-93.

Rodríguez Monegal, Emir. "Relectura de Pedro Páramo.” Fell, pp. 744-51. 
Rulfo, Juan. Pedro Páramo. Grove Press, 1994.

Russel Rourke, Brian. Mexicos of the Mind: British Writers of the 1930s in Mexico. Michigan: UMI, 1999

Sinyard, Neil. Graham Greene. A Literary Life. Palgrave Macmillan, 2003.

Watts, Cedric. "Janiform Greene: The paradoxes and pleasures of 'The Power and the Glory'." Dangerous edges of Graham Greene: journeys with saints and sinners, edited by Dermot Gilvary and Darren J. N. Middleton, Continuum, 2011, pp. 97-112.

Watts, Cedric. "Darkest Greeneland: Brighton Rock." Graham Greene Studies, vol. 1, 2017, pp. 133-44.

\title{
DRAMATYZACJA OBCEJ PRZESTRZENI W POWIEŚCI MOC I CHWAŁA GRAHAMA GREENE'A: PONOWNA WIZYTA W GREENELAND
}

\author{
Streszczenie
}

Graham Greene często podróżował i akcja jego książek często ma miejsce w różnych zakątkach świata. Mimo to krytycy są zgodni, że w swych powieściach Greene stworzył a-topos - przestrzeń odzwierciedlającą rozwój tematów (czy to duchowych, czy politycznych) zajmujących autora, a nie konkretne rzeczywiste miejsce. $Z$ czasem ów a-topos otrzymał nazwę Greeneland. Niniejszy artykuł stawia tezę, że krytycy, skupiając się na głównych motywach w twórczości Greene'a, ignorują fakt, że dokładna analiza świata przedstawionego podważa powszechnie panujące przekonanie, jakoby Greene wykreował w swojej twórczości przestrzeń mentalną, nie-miejsce. W celu dowiedzenia postawionej tezy, artykuł analizuje reprezentację przestrzeni i społeczeństwa w Mocy i chwale (1940), powieści, której akcja toczy się podczas religijnych prześladowań w Meksyku w latach dwudziestych dwudziestego wieku. Porównuję utwór Greene’a z powieścią Pedro Páramo Juana Rulfo (1955), gdyż powieść ta opisuje ten sam okres, a krajobrazy w niej opisane przypominają te z powieści Greene'a. Tym samym artykuł proponuje redefinicję idei Greeneland.

Słowa kluczowe: Greene; Rulfo; Moc i chwała; Pedro Páramo; Greeneland. 